\title{
Implementasi Inovasi Teknologi Sistem Penyediaan Hijauan Makanan Ternak Di Lahan Kering di Yogyakarta
}

\author{
DOI 10.18196/pt.2015.047.107-113
}

\author{
Supriadi \\ Balai Pengkajian Teknologi Pertanian Yogyakarta, \\ Jl. Stadion Maguwoharjo No. 22 Wedomartani Ngemplak, Sleman Yogyakarta, Indonesia, Telp. (0274) 884662, \\ e-mail: supri.yadi20@yahoo.co.id
}

\begin{abstract}
ABSTRAK
Keberhasilan pengembangan pertanian tergantung kepada keberhasilan dalam pengoptimalan pemanfaatan sumberdaya alam yang dimiliki. Potensi sumber ketersediaan hijauan pakan berdasarkan sumberdaya lahan yang ada kemungkinan di setiap daerah akan terdapat perbedaan, perbedaan ini penting sekali untuk di ketahui karena akan menentukan model pengembangan usaha peternakan selanjutnya. Dari hasil identifikasi permasalahan pengembangan peternakan di lahan kering diantaranya adalah (1) Ketersediaan pakan pada musim kemarau sangat kurang; (2) Jarak beranak (calving interval) yang panjang; (3) Kesuburan tanah rendah dan tenaga kerja terbatas. Fermentasi kelobot jagung dan fermentasi jerami padi dapat meningkatkan kandungan protein dan dapat meningkatkan kecernaan. Penyediaan hijauan pakan dengan penanaman jagung pola rapat 4 kali penjarangan mendapatkan hijauan sebanyak 22,5 ton/ha dan jagung pipilan kering sebanyak 4,2 ton/ha. Perbaikan pola tanaman dapat memberikan jaminan ketersediaan hijauan sepanjang tahun. Penanaman rumput hermada di lahan kering dapat memproduksi hijauan 35,56 ton/ha atau dapat menampung 3,3 unit ternak / tahun. Peningkatan produksi jerami padi dari IP 300 ke IP 400 dapat meningkatkan produksi jerami padi hingga 30\%. Perbaikan kualitas pakan di tingkat petani dengan melakukan fermentasi klobot jagung dengan pemeraman selama 14 hari ditambah dengan 2\% urea dapat mengandung protein kasar berkisar antara 4,8\% sampai dengan 8,4\%. Fermentasi jerami padi dengan penambahan 1 kg probiotik dan 2 kg urea untuk 500 kg jerami padi kering dapat menghasilkan kualitas jerami yang beraroma dan bertekstur lunak.

Kata kunci: Hijauan pakan, Lahan kering, Ternak
\end{abstract}

\begin{abstract}
The successful development of agriculture depends on the success in optimizing the utilization of natural resources owned. Potential sources of forage availability based on land resources is possible in each area there will be a difference, this difference is very important to be in the know as it will determine the further development model farm. From the results of the identification of problems in dryland farm development include (1) The availability of food in the dry season is very less; (2) Distance birth (calving interval) long; (3) low soil fertility and limited manpower. Fermented corn husk and rice straw fermentation can increase the protein content and improve digestibility. Provision of forage with corn planting pattern thinning meeting four times to get forage 22.5 tonnes / ha and corn dry as much as 4.2 tons / ha. Improvements pattern plants can guarantee the availability of forage throughout the year. Hermada grass planting in dry soil can produce forage 35.56 tonnes / ha or can accommodate 3.3 livestock units / year. Increased production of rice straw IP 300 and IP 400 can increase the production of rice straw up to 30\%. Feed quality improvements at the farm level by fermenting corn husks with curing for 14 days plus 2\% urea may contain crude protein ranged from 4.8\% to 8.4\%. Fermented rice straw by addition of $1 \mathrm{~kg}$ of probiotics and $2 \mathrm{~kg}$ of urea to $500 \mathrm{~kg}$ of dry rice straw can produce quality hay-scented and soft textured.

Keywords: Livestock forage, Dryland, Fodder
\end{abstract}

\section{PENDAHULUAN}

Wilayah lahan kering di Daerah Istimewa Yogyakarta merupakan salah satu wilayah pembangunan pertanian yang mendapat perhatian serius untuk ditangani melalui program integrasi usahatani tanaman (tanaman pangan atau tanaman tahunan) dan usaha peternakan, karena sebanyak 721.496 orang yang sebagian besar petani, tinggal dan menempati lahan seluas 158.600 ha sebagai sumber kehidupan mereka. Lahan tersebut tersebar di 26 Keca- matan di wilayah administrasi D.I. Yogyakarta, 17 Kecamatan diantaranya termasuk ke dalam kelas penggunaan lahan yang riskan terhadap erosi tanah dan bersolum dangkal (World Bank, 1991).

Di wilayah Daerah Istimewa Yogyakarta limbah pertanian telah menjadi tumpuan sumber hijauan pakan sepanjang tahun. Produksi limbah pertanian di wilayah ini diperkirakan sebanyak 765.184 ton bahan kering/tahun; diantaranya 
berupa jerami padi sebanyak 478.222 ton bahan kering (Utomo, 1999). Upaya mengoptimalkan pemanfaatan limbah pertanian dilakukan dengan berbagai cara. Untuk mengatasi fluktuasi ketersediaan limbah pertanian, petani telah melakukan pengeringan untuk menyimpannya sebagai persediaan yang tidak hanya digunakan pada saat sulit pakan, bahkan digunakan sepanjang tahun. Supriadi dkk. (1999) Berdasarkan hasil pengkajian di lahan kering Gunungkidul bahwa ketahanan pakan hijauan ditentukan oleh pola tanam yang sedang berjalan. Krisis pakan hijauan umumnya terjadi pada bulan Juni hingga bulan Oktober, yaitu pada saat musim kemarau. Pola tanam yang ada baik di lahan tegalan ataupun di lahan pekarangan hanya dapat menyediakan limbah pertanian di saat musim hujan, namun pada saat musim kemarau limbah pertanian yang ada tinggal hijauan kering dan ramban dari pekarangan dengan jumlah terbatas. Limbah pertanian yang berupa tongkol jagung, jerami kacang, kulit kacang, batang ubikayu yang biasanya tidak dijadikan pakan ternak, setelah digiling dan dicampurkan dengan konsentrat akan menjadi complete feed yang dapat mengatasi krisis pakan di saat musim kemarau.

Banyak peternak di lahan kering yang mengalami kendala kesulitan mendapatkan hijauan pakan, terlebih lagi pada musim kemarau dimana produksi hijauan turun drastis, sedangkan populasi ternak relative tetap sehingga seakanakan terlalu banyaknya ternak yang dipelihara saat itu melampaui kemampuan alam untuk menyediakan hijauan pakan, keadaan ini sangat tidak mendukung terhadap usaha peningkatan populasi ternak.

Kemampuan reproduksi yang rendah sering dijumpai pada ternak betina ditingkat petani yang diawali sejak ternak usia muda, kekurangan pakan berakibat dewasa kelamin terlambat, bah- kan dibeberapa daerah di jumpai uterus tidak berkembang optimal (terlalu kecil) menurut para ahli ilmu nutrisi kelainan bentuk uterus terlalu kecil ini kemungkinan disebabkan kekurangan gizi pakan (mal nutrition) dalam jangka waktu yang cukup panjang terutama pada saat ternak dalam masa pertumbuhan, kondisi ini berulang kali terjadi disaat musim kemarau. Kait mengkait antara usaha peningkatan populasi ternak dengan kendala yang ada seperti kesulitan penyediaan pakan yang baik dan kontinu serta sering terjadi kelainan reproduksi, mendorong untuk menguraikan permasalahan yang selalu terjadi pada usaha peternakan di lahan kering.

Usaha peternakan memberikan kontribusi yang besar terhadap pendapatan keluarga, berbagai permasalahan yang dihadapi dalam usahatani ternak khususnya sapi di lahan kering adalah:

\section{Ketersediaan pakan ternak pada musim}

kemarau kurang. Kondisi tanaman dilahan kering baik itu tanaman pangan maupun tanaman pakan ternak sangat tergantung pada musim, pada saat musim hujan air melimpah, tanaman tumbuh dengan subur baik itu tanaman pangan maupun tanaman pakan sehingga, ternak tidak kekurangan pakan. Tetapi sebaliknya pada saat musim kemarau air kurang, tanaman produktivitasnya sangat rendah dan bahkan banyak yang mati sehingga menyebabkan ternak kekurangan air dan pakan hijauan. Jalan keluar yang biasanya petani lakukan untuk mengatasi kekurangan hijauan dengan pemberian jerami padi, namun demikian jerami memiliki lignoselulosa dengan kadar lignin dan silikat yang tinggi yang menyebabkan daya cerna menjadi rendah (Suwandyastuti, 1988). Ketersediaan pakan yang terbatas, diikuti kualitas yang rendah berakibat pada perkembangan ternak secara umum yang rendah. Hasil pengkajian Supriadi dkk. (1999) terhadap 
623 ekor sapi jantan dan 567 ekor sapi betina pertambahan berat badannya masing berkisar 0,340 - 0,459 kg/erkor/hari dan 0,159-0,326 $\mathrm{kg} / \mathrm{ekor} / \mathrm{hari}$.

Jarak beranak (calving interval) yang panjang. Hal ini terjadi dikarenakan tingginya jumlah kegagalan kebunting dalam satu kali perkawinan atau angka service per conseption (S/C) yang tinggi, hal ini bisa disebabkan dari asupan gizi pakan yang kurang baik dan berlangsung lama seperti pada saat musim kemarau, sehingga menyebabkan alat reproduksi kurang berkembang dengan baik. Pola dan pemberian pakan yang belum sesuai dengan kebutuhan ternak, dilaporkan merupakan faktor utama rendahnya tingkat produktivitas ternak di daerah tropis (Chen, 1990). Hasil pengkajian Supriadi dkk. (1999) di DIY pada 13 kelompok tani dijumpai 26\% - 36,35\% sapi betina bermasalah, hal ini akibat dari petani dalam melaksanakan usahaternaknya hanya sebagai usaha sampingan sehingga kurang tanggap terhadap pentingnyan arti kualitas pakan yang berhubungan dengan kemampuan reproduksi ternaknya. Supriadi dkk. (2006) mendapatkan hasil pengkajian di DIY bahwa pemeliharaan sapi potong di tingkat petani masih sederhana, baik ditinjau dari hijauan pakan yang diberikan maupun kondisi perkandangannya sehingga menyebabkan nilai ADG pada pedet umur 1-1,2 tahun yang sangat rendah, persentase induk bunting terhadap populasi yang rendah hanya mencapai $22,9 \%$, dengan S/C yang tinggi hingga mencapai 5. Namun demikian petani tidak akan menjual habis ternaknya sekalipun pada saat musim kemarau akan menghadapi kesulitan hijauan pakan, dikarenakan petani sangat membutuhkan pupuk kandang untuk kesuburan lahannya.

Kesuburan tanah yang rendah dan tenaga kerja terbatas. Tanah lahan kering umumnya memiliki kesuburan yang rendah, kemasaman tanah tinggi; kahat P, K, Ca dan Mg; kejenuhan basa dan bahan organik umumnya rendah; kadar AL dan Mn tinggi yang dapat bersifat toksik bagi tanaman (Adiningsih dan Rochayati, 1987). Sedangkan kendala kesuburan fisik adalah sangat peka terhadap erosi, pori aerasi tanah rendah terutama di lapisan bawah sehingga tanah memadat, akibatnya infiltrasi lambat, erosi dan aliran permukaan bertambah besar, rendahnya ketersediaan air sebagai akibat pemadatan dan rendahnya kandungan bahan organik.

Disamping terkendala kesuburan tanah, juga terbatasnya tenaga kerja, Sebagai sumber daya manusia yang ada atau yang tertinggal disetiap rumah tanggal petani di wilayah lahan kering umunya berkisar antara 2 - 3 orang yaitu; 1 orang ayah; 1 orang ibu dan 1 orang anak lakilaki atau perempuan,sedangkan anggota keluarga yang lainnya biasanya pergi merantau ke kota besar mencari kehidupan yang lebih baik.

Kondisi tenaga kerja yang terbatas tersebut akan sulit untuk mengembangkan usahatani, oleh sebab itu diperlukan teknologi yang hemat tenaga namun tepat sasaran seperti teknologi fermentasi jerami; teknologi fermentasi klobot jagung, teknologi pembuatan kompos dengan mengunakan bumbung dan menerapkan penamanan jagung rapat sebagai pola tanam dwifungsi.

\section{HASIL DAN PEMBAHASAN}

Sistem Penyediaan Hijauan Makanan Ternak Penyediaan Hijauan Makanan Ternak (HMT) Melalui Penanaman Jagung Jarak Rapat

Salah satu andalan sumber hijauan pakan ternak di daerah lahan kering adalah limbah pertanian, baik dalam keadaan segar maupun dalam keadaan kering seperti halnya jerami, namun demikian jerami memiliki lignoselulosa dengan 
kadar lignin dan silikat yang tinggi yang menyebabkan daya cerna menjadi rendah (Suwandyastuti; 1988). Limbah pertanian sangat bergantung kepada budidaya pertanian terutama pertanian tanaman pangan diantaranya tanaman jagung baik sebagai penghasil jagung pipilan maupun sebagai penghasil pakan (tebon).

Hasil pengkajian Supriadi dkk. (2008). Di Pedusunan Toboyo Timur, menanam jagung dengan pola tanaman rapat yang bertujuan untuk mendapatkan jagung pipilan dan sekaligus mendapatkan tebon dari hasil penjarangan, hasilnya dapat dilihat pada Tabel 1 dibawah ini.

Tabel 1. Rerata hasil jagung pipilan kering dan Tebon (Hijauan pakan) di Toboyo Timur Plembutan, Playen Gunungkidul, 2008

\begin{tabular}{llll}
\hline No. & Perlakuan & Pipilan kering (ton/ha) & Hijauan ton/ha) \\
\hline 1 & 4 kali cabut & 4,2 & 22,5 \\
2 & 2 kali cabut & 4,6 & 19,9 \\
3 & 2 kali cabut dalam rumpun & 3,4 & 13 \\
4 & Tanpa pencabutan/ pola petani & 6,5 & 1,2 \\
\hline
\end{tabular}

Sumber: Supriadi dkk. (2008)

Dari Tabel 1 terlihat bahwa penanaman jagung rapat dengan 4 kali pencabutan cukup memberikan prospek untuk dikembangkan, dikarnakan selain dapat menghasilkan pakan (tebon) yang cukup tinggi 22,5 ton/ha juga menghasilkan jagung pipilan kering sebanyak 4,2 ton/ha, dan yang paling penting dari penuturan petani bahwa pola tanaman rapat dengan 4 kali pencabutan dapat menghasilkan tebon yang merata sepanjang minggu karena jarak pencabutanya tidak terlalu jauh, sehingga membantu meringankan petani dalam mencari pakan.

\section{Penyediaan Hijauan Makanan Ternak (HMT) Me-} lalui Sistem Pola Tanam

Sistem pertanaman (pola tanam) yang dilakukan oleh petani lahan kering umumnya mengikuti pola curah hujan . Pola tanam dalam satu tahun dengan sistem tumpangsari yang umum dilakukan di lahan kering bukan hanya dapat mengurangi resiko kegagalan panen, tapi juga dapat memberikan keuntungan terhadap produksi pakan ternak dari limbahnya. Dalam pola tanam antara tanam yang satu dengan tanaman yang lainnya dalam satu musim hujan selain bervariasi juga saling bersambungan, sehingga memungkinkan tersediaanya pakan ternak dari limbah pertanian. Hasil penelitian Supriadi dkk. 2004a) bahwa pada dasarnya ketersediaan hijauan sangat dipengaruhi oleh musim dan pola tanam yang dilakukan petani. Di desa Plembutan terdapat dua polatanam yang dominant, seperti terlihat pada Tabel 2 dibawah ini.

Tabel 2. Pola tanam dan ketersediaan limbah pertanian sebagai hijauan pakan berdasarkan musim tanam

\begin{tabular}{|c|c|c|c|}
\hline Musim & $\begin{array}{c}\text { MH } 1 \\
\text { (Nov- Jan/ Feb) }\end{array}$ & $\begin{array}{c}\text { MH } 2 \\
\text { (Feb-April/Mei) }\end{array}$ & $\begin{array}{c}\text { MK } \\
\text { (Juni-Okt) }\end{array}$ \\
\hline Pola tanam 1 & $\begin{array}{l}\text { Padi + Jagung + } \\
\text { Ubikayu + Turi }\end{array}$ & Kedelai+Jagung & Bero * \\
\hline \multirow[t]{3}{*}{ Pola tanam 2} & $\begin{array}{l}\text { Kc. Tanah + Jagung } \\
+ \text { Ubikayu + Turi }\end{array}$ & Kedelai+Jagung & Bero * \\
\hline & - Jerami padi & - Jerami kedelai & - Kulit ubikayu. \\
\hline & $\begin{array}{l}\text { - Jerami jagung } \\
\text { (tebon) }\end{array}$ & - Jerami jagung & - Daun ubikayu \\
\hline \multirow[t]{3}{*}{$\begin{array}{l}\text { Jenis pakan/ limbah } \\
\text { pertanian }\end{array}$} & - Rumput & - Rumput. & - Turi. \\
\hline & - Tayuman & - Tayuman & - Tayuman. \\
\hline & $\begin{array}{l}\text { - Jerami kacang } \\
\text { tanah }\end{array}$ & & - Ramban \\
\hline
\end{tabular}

Sumber: Supriadi (2004a)

* Walaupun bero masih terdapat ubikayu

Penyediaan Hijauan Makanan Ternak (HMT) Melalui Penanaman Rumput Hermada (Sorghum vulgara sudanense)

Berdasarkan hasil penelitian, Supriadi (2004b) penanaman rumput hermada di lahan kering, baik faktor volume maupun interval penyiraman ternyata tidak memberikan pengaruh tehadap pencapaian tinggi tanaman hermada, begitu pula terhadap bobot basah maupun bobot keringnya. Daya tampung ternak dari rataan hasil bobot basah tanaman hermada setiap hektarnya 
sebesar 35,65 ton dan bobot kering sebanyak 12,50 ton, dapat menampung ternak sebanyak 3,3 unit/tahun.

Supriadi (2004c) menyatakan bahwa enanaman rumput hermada dilahan kering dengan menggunakan beberapa jenis pupuk organik (Azolla sp., Bokasi dan Eceng gondok) tidak menunjukan pengaruh terhadap pertumbuhan (tinggi tanaman, diameter batang, bobot basah dan bobot kering), namun dari beberapa dosis yang diberikan untuk setiap jenis pupuk dapat memberikan pengaruh terhadap pertumbuhan rumput hermada. Bobot basah dan bobot kering hijauan rumput hermada yang paling tinggi adalah pada dosis 10 ton/ha baik pada jenis pupuk Azola maupun pada jenis pupuk Bokasi. Daya tampung ternak berdasarkan bahan kering yang diproduksi pada jenis pupuk Bokasi dengan dosis 10 ton/ha yaitu dapat menampung 827 unit ternak/hari dan yang kedua adalah pada jenis pupuk Azolla sp. dengan dosis sebanyak 10 ton/ha yaitu dapat menampung sebanyak 750 unit ternak/hari.

Hasil penelitian Supriadi dkk. (2006) menyatakan bahwa penanaman sorgum di lahan kering pada jenis sorgum (Sorghum bicolor (L.) Moench) mendapatkan hasil bahwa terdapat perbedaan yang nyata antara kandungan protein beberapa galur sorgum mutan (B-69, B-72, B-76, B-83, B-90, B-92, B-95, B-100) dengan varietas unggul Nasional (UPCA dan Higari). Rata-rata kandungan protein galur sorgum mutan lebih rendah dari pada sorgum varietas unggul Nasional yaitu 1,885\% berbanding 2,17\%. Ditinjau dari produksi hijauan kering, estimasi produksi riil protein kasar, serat kasar dan lemak kasar maka sorgum dengan nomor asisi B-92, B-95 dan B-100 dapat direkomendasikan untuk dibudidayakan dilahan kering karena mengandung protein kasar yang lebih tinggi dibanding yang lain, seperti terlihat pada tabel dibawah ini:

\section{Penyediaan Hijauan Makanan Ternak (HMT) Melalui Pemanfaatan Jerami Padi Sawah Tadah Hujan}

Hasil penelitian Supriadi dkk. (2007a), penanaman padi VUB Sintanur pada sawah tadah hujan di Desa Semin dengan sistem tumpang sari dapat menyediakan hijauan pakan bukan hanya bervariasi namun juga dapat kontinyu sepanjang tahun, dan penaman pada musim tanam kedua dapat menyediakan hijauan kering untuk persediaan pakan pada saat musim kemarau. Dalam satu hektar tanaman padi VUB Sintanur dapat menyediakan pakan ternak sebarat $350 \mathrm{~kg}$ selama 416 hari atau untuk pakan 2 ekor sapi selama 6,9 bulan.

Penyediaan Hijauan Makanan Ternak (HMT) Melalui Pemanfaatan Jerami Padi Sistem Tegel Dan Legowo Menuju IP 400

Hasil penelitian Supriadi dkk. (2010), produksi biomasa penanaman padi sisten tegel antara pemupukan urea pril dan urea tablet tidak ada perbedaan namun produksi biomasa cenderung lebih tinggi pada urea tablet, kemudian pada peningkatan penanaman padi dari 3 kali menjadi 4 kali melalui penanaman varietas berumur genjah dapat meningkatkan produksi jerami 30\% setiap tahunnya, produksi biomasa (jerami) sebanyak 207,52ton/tahun pada IP 400 memiliki daya tampung ternak sebanyak 133 satuan unit ternak pertahun pada luasan sawah seluas $63.269 \mathrm{~m}^{2}$ selanjutnya Supriadi dkk. (2010) melakukan pengamatan pada kandungan nutrisi jerami sebagai pakan ternak bahwa pemberian urea tablet dengan cara dibenamkan dan pemberian urea prill dengan cara disebarkan pada pertanaman padi varitas silugonggo dan padi varitas dodokan mendapatkan kandungan nutrisi pada jerami kedua varitas tersebut tidak 
menunjukkan perbedaan. Penggunaan pupuk urea tablet pada varitas dodokan mendapatkan jumlah protein kasar 5,5\% yang jauh lebih tinggi dibandingkan dengan pengunaan urea pril yaitu sebesar $4,75 \%$.

\section{Penyediaan Hijauan Makanan Ternak (HMT) Me- lalui Penanaman Rumput di Bibir Teras}

Lahan kering di Daerah Istimewa Yogyakarta umumnya memiliki tofografi berlereng dengan kemiringan diatas 30\% sampai dengan 45\%, lahan-lahan yang demikian umumnya arawan terhadap erosi akibat aliran permukaan, salah satu pencegahannya adalah dengan pembuatan terasering, untuk memperkuat teras perlu dilengkapi dengan penanaman rumput di bibir teras, selain dapat memperkut teras juga untuk menahan erosi tanah. Hasil penelitian Supriadi dkk (1997). Di wilayah Cangkringan, Sleman. Produksi rumput yang ditanam di tampingan dan bibir teras pada rumput Brachiaria brisantha; rumput raja dan rumput gajah yang ditanaman 2 baris masing-masing berproduksi 2970; 2932,5 dan $1065 \mathrm{~kg} / 1500$ panjang teras. Hasil penelitian Hafif dkk (1995) erosi yang dapt dicegah dari penanaman rumput di bibir dan tampingan teras adalah sebesar 3,4 - 5 ton/ha/tahun.

\section{Penyediaan Hijauan Makanan Ternak Melalui Sistem Fermentasi Limbah Pertanian \\ Fermentasi Klobot Jagung. Penyediaan} hijauan pakan ternak yang merupakan pakan pokok ruminansia pada akhir-ahkir ini terasa semakin sulit dan terbatas, hal ini disebabkan karena semakin berkurangnya lahan pertanian sebagai sumber penyediaan pakan hijauan. Keadaan ini mendorong kita untuk mencari alternatif pemanfaatan limbah pertanian paca panen dimana tidak lagi hanya terbatas pada jerami, tetapi bagian lain yang masih dapat dimanfaatkan seperti klobot dan tongkol jagung. Hasil penelitian Supriadi dkk. (2000) kandungan protein kasar pada slamper, klobot dan jerami yang telah diberi perlakuan dengan penambahan $2 \%$ urea dan probiotik setelah di peram selama 14 hari mengandung protein berturut-turut sebesar 6,8\%, 4,8\%, dan 8,4\%.

Fermentasi Jerami Padi. Jerami padi merupakan limbah tanaman padi yang nilai nutrisinya rendah, oleh sebab itu perlu diperlakukan terlebih dahulu sebelum diberikan pada ternak, yaitu dengan cara difermentasikan untuk meningkatkan daya cernanya.

Hasil pengkajian Supriadi dkk. (2007b) yang dilakukan di wilayah laboratorium Prima Tani yaitu di Dusun Karangpoh menunjukan bahwa, $500 \mathrm{~kg}$ jerami padi yang difermentasi dengan $1 \mathrm{~kg}$ probiotik ditambah dengan $2 \mathrm{~kg}$ urea menghasilkan jerami fermentasi yang baik dengan aroma yang tidak menyengat, tekstur lunak dan warna yang terang, hasilnya dapat dikeringkan dan disimpan sebagai cadangan pakan dimusim kemarau.

\section{SIMPULAN DAN SARAN}

Dari hasil identifikasi permasalahan pengembangan peternakan di lahan kering diantaranya adalah

1. Ketersediaan pakan pada musim kemarau sangat kurang

2. Jarak beranak (Calving Interval) yang panjang

3. Kesuburan tanah rendah dan tenaga kerja terbatas

Penyediaan hijauan pakan dengan penanaman jagung pola rapat 4 kali pejarangan mendapatkan hijauan sebanyak 22,5 ton/ha dan jagung pipilan kering sebanyak 4,2 ton/ ha. Perbaikan pola tanaman dapat memberikan jaminan ketersediaan hijauan sepanjang tahun. Penanaman rumput hermada di lahan kering 
dapat memproduksi hijauan 35,56 ton/ha atau dapat menampung 3,3 unit ternak / tahun. Peningkatan produksi jerami padi dari IP 300 ke IP 400 dapat meningkatkan produksi jerami padi hingga 30\%. Perbaikan kualitas pakan di tingkat petani dengan melakukan fermentasi klobot jagung dengan pemeraman selama 14 hari ditambah dengan 2\% urea dapat mengandung protein kasar berkisar antara 4,8\% sampai dengan $8,4 \%$. Fermentasi jerami padi dengan penambahan $1 \mathrm{~kg}$ probiotik dan $2 \mathrm{~kg}$ urea untuk $500 \mathrm{~kg}$ jerami padi kering dapat menghasilkan kualitas jerami yang beraroma dan bertekstur lunak. Khusus diwilayah lahan kering yang memiliki tofografi bergelombang dan berteras-teras dapat memanfaatkan bibir teras untuk lahan penanaman rumput, penanaman strip rumput di bibir dan tampingan teras dapat menahan erosi tanah 3,4 - 5 ton/ha/tahun.

Di wilayah lahan kering akan selalu terjadi kekurangan pakan dimusim kemarau dan ini selalu terulang di setiap tahun oleh karena itu diperlukan adanya usaha pengkajian untuk mencari kesesuaian antara usahatani tanaman pangan dan peternakan khususnya dalam perbaikan pola tanaman dengan harapan pola tanam tersebut terus berkelanjutan dari musim kemusim sepanjang tahun sehingga ada jaminan ketersedian pangan dan pakan dari limbah pertanian.

\section{DAFTAR PUSTAKA}

Adiningsih,J.S. dan Sri Rochayati. 1987. Peranan bahan organik dalam meningkatkan efisiensi penggunaan pupuk dan produktivitas tanah. Proc. Lokakarya Nasional Efisiensi Pupuk . Pusat Penelitian Tanah. Badan Littbang Pertanian.

Chen, C.P. 1990. Management of Forage for Animal Production under Tree Crops. In: Proc. Integrated Tree Croping and Small ruminat Production system. Iniques L.C. and M.D. Sanchez (Eds). SR-CRSP. Univ. California Davis, USA. 